УДК 929 Караџић, Вук Стефановић https://doi.org/10.18485/msc50_vuk_trsic.2021.ch26

\author{
Петар Динеков
}

\title{
ЛИЧНОСТ ВУКА КАРАЏИЋА
}

Личност Вука Караџића заузима посебно место у његовој великој и разноврсној делатности. Овде није неопходно да дајем карактеристику стваралаштва Вука Караџића у области језика, књижевности, фолклора, етнографије, географије, историје, критике, педагогике, превода, политичког живота. Одушевљава нас ширина књижевних и научних интересовања, духовна енергија и стваралачка воља овог великог сина српског народа. Историју несумњиво занимају пре свега резултати његове делатности - они се анализују, у њима се истражују моралне вредности, они условљавају друштвено, национално и међународно значење делатности. У њима се крије и величанственост историјске личности.

Нема сумње да су делатност и личност нераздвојно повезане; у свакој делатности уграђена је личност са својим индивидуално-психолошким особинама. И она не може а да не привуче нашу пажњу. Личност се најчешће спаја са делатношћу, раствара се у њој. Али Вук Караџић је посебна, необична личност, која у оквирима своје делатности живи свој живот како у свести својих савременика, тако и у сећању следећих генерација. Можда звучи парадоксално, али личност сија властитом светлошћу и својим сјајним блеском ствара нове димензије делатности. Навешћу примере из историје бугарске књижевности - то су Г. С. Раковски и Неофит Бозвели, савременици Вука Караџића. Бурни живот Раковског и његова искључива личност најлепши су роман који је он створио, иако га није могао написати. Осврћући се на делатност Бозвелија наш чувени историчар књижевности пише: „Неофита Бозвелија треба проучавати пре свега као личност, јер је у овом случају личност интересантнија од књижевних дела и једино захваљујући њој постају занимљива и сама дела. Његове идеје имају смисао само кад их повежемо са његовим индивидуалним квалитетима - само у овом случају оне могу имати животну вредност, у случају када се схвати да је њихов извор у самом карактеру Неофита Бозвелија, у његовим властитим квалитетима. Само у таквом 
случају идеја излази из оквира теорије и претвара се у једну неодвојиву одлику живог човека - и схвата се као жива стваралачка снага"'. Навешћу још једну мисао Б. Пенева: „Историја се мора осећати тако што осећамо једно уметничко дело - али је она најсадржајније, највеће и најсложеније уметнико дело"2.

Враћајући се Вуку Караџићу, морам нагласити да његов случај не припада категорији када личност надживи делатност. Његова делатност је жива, заузела је место дубоко у основама српске културе, она је њена трајна суштина, живи у „вечитом” времену. У овом погледу од важног значаја је и личност Вука Караџића. У личности и делатности се реализује историја; оне се претварају у оно најсадржајније, највеће и сложено уметничко дело, о коме говори Б. Пенев.

Личност Вука Караџића носилац је одређене свести - „виши облик психичког одраза стварности, које одликује једино човека"з, према томе може бити предмет анализе са тачке гледишта филозофије, социологије и психологије. Мој задатак је скромнији: да наведем само неколико црта Вукове личности, које се односе углавном на социјалне карактеристике, али без вулгарне социологизације, код које се личност одређује једино као збир друштвених односа. ${ }^{4}$ Зауставићу пажњу пре свега на карактеру и способности у њиховој вези са спецификом историјског доба. У вези с тиме од користи ће бити и нека упоређења са бугарским културним развојем XIX века. Реч није о изједначавању појава по специфичности и величини, већ о заједничим тенденцијама националног препорода Срба и Бугара. Циљ ће бити да се изнесу паралеле између личности са знатно израженом социјалном осетљивошћу.

У огромној по значењу делатности Вука Караџића искрсава изузетна, свестрано развијена личност, пуна високих моралних квалитета, динамична, усмерена и храбра, личност генијалног самоука, реформатора и револуционара. Ми посматрамо необичну појаву: сложени пут „малог човека” (како сам себе зове у предговору Мале простонародне славено-српске песнарице из 1814 г.), који, иако потиче из скромне сеоске средине, достиже врхове европске културе XIX века и конверзира са њеним највећим представницима. Биографија Вука Караџића добро илуструје овај пут, који пролази кроз многобројне, бескрајне тешкоће.

1 Б. Пенев, История на новата бльгарска литература, Том II, София, 1977, c. 546 .

${ }^{2}$ Нав. дело, стр. 547.

${ }^{3}$ К. К. Платонов, Структура и развитие личности, Москва, с. 62.

${ }^{4}$ Нав. дело, с. 24-26. 
To је, пре свега, школовање, које стиче путем самообразовања. Још једна важна сметња на том путу је обољење, због кога Вук остаје инвалид до краја свог живота. Такође тешко му је и материјално стање, о којем закључујемо по његовим писмима, као и чињеница да он стално мења своје пребивалиште - лута земљом, бежи у иностранство. Бекство има и своју позитивну страну - одговара његовом динамичном карактеру, претвара се у обилазак Европе, где се сусреће са чувеним личностима које га разумеју и подржавају - почевши од Ј. Копитара па до Гетеа. Круг његових пријатеља, покровитеља и следбеника се стално шири; његове реформаторске идеје о карактеру језика, правописа и књижевности пробијају себи пут; његова дела (зборници народних песама, граматика, речник српског језика) наилазе на широку подршку у научном свету, па и више - доносе му европску славу. Али напади на њега и клевете се настављају. Упркос томе што има следбеника, његова правописно-језичка реформа прихвата се званично тек 1868. године (четири године после његове смрти). Вук је приморан да се брани, он непрекидно полемизира. Његови непријатељи такође се упорно боре - 1852. године забрањено је уношење Вукових књига у Србију. Називају га увредљивим изразом „хроми антихрист”. Али „хроми антихрист” обилази Европу и проноси славу једне велике националне ризнице - српске народне песме. Проноси славу - ако можемо тако рећи - и своје изузетне личности, која свугде наилази на симпатије, захваљујући својој изузетној оригиналности.

У току читавог свог живота Вук Караџић испољава чврстину карактера, доследност убеђења, храброст у полемикама, веру у правичност својих идеја и високу грађанску одважност у друштвеним питањима. Нећу овде карактерисати његову политичку делатност, али не могу а да не наведем његово опширно писмо кнезу Милошу од 12. IV 1832. године, као и писмо од $24 . \mathrm{X}$ исте године. Они представљају обрасце грађанског понашања.

Необична је проницљивост којом Караџић решава питања о карактеру српског језика, правописа и књижевности. Он категорично формулише кратак и јасан принцип: пиши као што говориш, а читај као што је написано. На основу овог принципа изграђена је читава језичка теорија. Нема сумње да Вук Караџић долази до ње путем знања која стиче. Од својих претходника он високо цени Доситеја Обрадовића, који je 1783. године први пут изјавио „да треба писати Српским језиком као што народ говори, и сам је почео, колико је знао, тако писати. За њим су пошли млоги учени Србљи, и за ово 35 година написали различне (тобоже Српске) књиге; али (за превелико чудо!) до данас још немамо ни једне књиге да је управо написана по Српској граматици, као што народ 


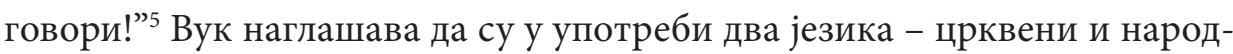
ни; паметни људи на високим положајима као што су митрополит Стратимировић и архимандрит Кенгелац, сматрају да је прави српски језик црквени, док је народни - покварени старословенски ${ }^{6}$. Дубоко убеђење Караџића заснива се не само на основу знања која је стекао, већ и на основу способности да критички уђе у суштину ствари. Овде му помаже чињеница да је био добар познавалац народа, народне културе. У основи тог познавања је љубав према народу, према народном животу, према народном стваралаштву. Његово родољубље је у ствари демократизам тиме се карактерише читава његова научна делатност.

Личност Вука Караџића се испољава на посебан начин у његовој фолклористичкој делатности. Потпуно је јасно да су проблеми језика и фолклора органски повезани. Народни језик најбоље се репрезентује у фолклору. Ово је једна страна проблема. Друга се односи на улогу народног стваралаштва као народне књижевности (није случајно да је прихваћен термин „народна књижевност”, слично пољском „literature ludowa"). Фолклорни модел утврђује се као књижевни; управо за такав тип књижевности бори се Караџић својим изврсним зборницима српских народних песама. Вук Караџић даје снажан импулс моћном покрету за јачање националног самоосећања - открива свет који може да се упореди са Хомеровим узорима (према оцени Ј. Грима).

У доба романтизма расте интерес за народно стваралаштво; фолклористичка делатност Вука Караџића једна је од његових најизразитијих карактеристика. Интересовања самоуког Караџића резултат су пре свега унутрашњег осећања. Током времена млади српски фолклориста упознаје се са основним идејама европске фолклористике. У његовом односу према народном стваралаштву постоји један важан моменат: смисао за уметност. Ово одређује основни правац његове скупљачке и издавачке делатности. Понекад се критикује уреднички рад Вуков, али ја сам убеђен да је он поступао правилно: одрастао је у атмосфери фолклора, потиче из рода народних гуслара и певача, непосредно је упознао народни стваралачки таленат и развијао свој жив смисао за естетику, непосредно се приближавајући народном укусу. Професор Ив. Д. Шишманов, који је припремао посебан рад о делатности Караџића, истиче следеће: „Данас ми знамо како је Вук Караџић састављао свој зборник. Доказано је да је из многих варијаната одабирао најлепше, најпотпуније и штампао је њих, не бојећи се да тексту дода или избаци из њега читаве

\footnotetext{
${ }^{5}$ Сабрана дела Вука Караиића, II, Београд, 1966, стр. V.

${ }^{6}$ Нав. дело, стр. XII.
} 
речи и слогове, како би исправио ритам песама, који обично представља петостопни јамб. Ово објашњава зашто је Вукова збирка стекла европско име. И досада она је једна од најрегуларнијих. Она је класична, али ова њена класичност, као што видимо, није таква захваљујући материјалу, већ захваљујући мајстору који је знао да вешто изабере тај материјал, да га критички прихвати и да га споји у једну систематску целину." Шишманов уздише: „Ми смо убеђени да смо имали и ми у оно доба... једног Вука, па и данас да се роди један човек његове воље, његовог смисла и његових способности, да би било могуће да се од свих народних песама, које имамо сакупљене до сада и које још нису записане, састави једна изврсна збирка, која би се у неком смислу могла упоредити са Вуковом7." Чини ми се да је 1889. године, када Шишманов пише ове речи, касно да се оживљава Вуков експерименат - прошло је доба романтизма, друго је стање народне песничке традиције; Вука не можемо поновити, иако је то покушавано.

Вук Караџић је не само фолклориста-скупљач и издавач већ и истраживач; његови савременици нису оценили ову његову врлину. Он даје интересантна запажања о поетици и функцији фолклора; први пут управо он даје драгоцене карактеристике народних певача; оцртава епске ликове Краљевића Марка, Милоша Обилића и других; решава теоретска питања; занима га фолклор других народа (записује бугарске, руске, румунске и албанске песме).

Личност Вука Караџића се открива и у његовој историографској делатности. Као историчар српских устанака он утврђује принцип: „Само да кажем како је било”. Али то не значи да је та проза безлична, јер аутор има активан однос према догађајима и појединим лицима. Анализа историјских дела Караџићевих допуњује његову карактеристику.

Покушао сам да уђем углавном у оне црте личности Вука Караџића које имају социјални карактер. Дабоме, тиме се не исцрпљује његов целовити лик. Караџић има свој интимни свет. Да узмемо, на пример, његову породицу; он доживљује трагедију оца којем умире 11 од тринаесторо деце. Таква судбина на свој начин моделира личност, чак и када она није усамљена, већ је тесно повезана са социјалном средином. Требало је имати велике моралне снаге како би се преживела туга.

Овде хоћу да наведем једна други моменат који је повезан са историјским типологијом дела и личности Вука Караџића. Јасно је да је са једне стране Вук изузетна индивидуалност високих моралних и инте-

7 Ив. Д. Шишманов, Значението и задачите на намета етнография, СбНУ, I, 1889 , c. 15. 
лектуалних врлина, а са друге - он је национална појава, значајна етапа у српском националном развитку. Он припада једном карактеристичном покрету јужнословенског региона прве половине XIX века, укључен је у један процес са два лица - јачање национално-патриотског самоосећања и тежња ка укључивању у културни живот Европе, тежња ка светском прогресу. Овај покрет иде различитим путевима - од школе до револуције. У вези са делатношћу В. Караџића, интересују нас два мометна: језик и фолклор. У овом правцу су и моје бугарске паралеле.

Делатност Вука Караџића је била позната у Бугарској још у XIX веку, у доба бугарског препорода; од тада почиње његов утицај на бугарски национални развитак ${ }^{8}$. Зауставићу се на две фигуре бугарских књижевника, лингвиста и фолклориста: то су Г. С. Раковски (1821-1867) и П. Р. Славејков (1827-1895), који су савременици Вука Караџића. Упоређење обухвата однос према језику и фолклору. Морам истаћи још један заједнички моменат - тешка лична и друштвена судбина. Раковски је сложена личност - човек пера и мача, писац, новинар, публициста, историчар, лингвиста, фолклориста, револуционар, организатор бугарског националног ослободилачког покрета, романтична личност која је провела свој живот у покрету (Турска, Србија, Грчка, Румунија, Француска) вођа револуционарног одреда у Старој планини и заробљеник у турским затворима. Једна случајна али интересантна чињеница: за време турског бомбардовања Београда 1862. г. Раковски и Караџић се налазе у граду. Живот П. Р. Славејкова је такође динамичан - као учитељ, он се сели из града у град, док се не заустави у Цариграду где ради - као писац, новинар, публициста широког погледа на свет, фолклориста, етнограф, историчар. Раковског и Славејкова повезује заједнички интерес према народном песничком стваралаштву, о чему сведоче њихова основна дела: Кажипрст Раковског и Бугарске приче или пословице и карактеристичне речи Славејкова. Али их разликује однос према језику. Раковски је присталица старине у романтично-родољубивом стилу, у својим размишљањима о старини бугарског језика иде далеко, архаизира тај језик и правопис да би сачувао његову везу са историјском традицијом. У свом односу према језику налази се у пуној супротности са схватањима В. Караџића. Супротни су Раковском и ставови Славејкова: као талентован песник и одличан позналавац народног језика он даје огроман допринос формирању савременог бугарског књижевног језика. Он каже да само

${ }^{8}$ В. литературу наведену у: П. Динеков, Дело Вука Каращића и бугарска филолошка наука у другој половини XIX века, Научни састанак слависта у Вукове дане, III, Београд, 1973, стр. 325-340. 
„проучавање народног, језика, језика који постоји у народу, његовог духа и одлика" може да нас руководи на тешком путу ка правилном развоју књижевног језика9. Славејков покушава да реформише азбуку, избацујући у првим бројевима свог листа „Гајда” (1863) крајње јерове. Мора да се наведе и дубока веза његовог песничког стваралаштва са народном песмом; ово би се могло рећи и за његову публицистику и хумор, који се у великој мери заснивају на разговорном народном језику.

Навео сам паралеле са делатношћу и личностима Г. С. Раковског и П. Р. Славејкова да бих истакао да између српских и бугарских посленика, учесника у једном заједничком покрету (Караџић, Раковски, Славејков) постоје велике разлике. Али истовремено наилазимо и на заједничке тенденције које их спајају. Спаја их хуманизам који је у основи њихове делатности. Спаја их у тренутку када траже нове видике развоја и окрећу се према просвећеној Европи, уједињује их тежња да не изгубе везу са народним језиком и народном културом. У њиховом комуницирању са светом ствара се нова култура, али је њена основа национална. Велику улогу у том погледу игра фолклор. Он се органски укључује у нове јужнословенске књижевности, не као нешто што се позајмљује и пресађује вештачким путем, већ као реално постојећи, природан ток.

Ето какве мисли изазива анализа личности Вука Караџића. Он је био активан учесник у процесу културног комуницирања Јужних Словена са Европом. Показао је свету естетске вредности српског фолклора, обогаћујући на тај начин европског човека новим уметничким доживљајима. У XIX веку Јужни Словени су углавном увозили културу, док је Вук Караџић био први, који ју је извозио. И ова заслуга без сумње припада њему.

* Рад је претходно објављен у зборнику Научни састанак слависта у Вукове дане, 17/5, 5-10.

9 П. Р. Славеиков, Съчинения. Том IV, София 1978, с. 442. 